\title{
Interleukin-12 Subunit Beta
}

National Cancer Institute

\section{Source}

National Cancer Institute. Interleukin-12 Subunit Beta. NCI Thesaurus. Code C28509.

Interleukin-12 subunit beta (328 aa, $237 \mathrm{kDa}$ ) is encoded by the human IL12B gene. This protein is involved in the growth of both natural killer cells and T-cells. 